\title{
DEOXYRIBONUCLEIC ACID AND GENETIC MODIFICATION IN DUCKS
}

\begin{abstract}
T was natural that the genetic transformation of bacteria effected by the introduction of foreign deoxyribonucleic acid should lead to speculation as to whether the phenomenon could also be induced in higher forms. That similar treatment should be capable not only of altering the racial characteristics of the growing vertebrate but that such changes would also be heritable seemed one of the least likely outcomes of such an experiment.

Recently published reports by Benoit et al. ${ }^{1}$ state that they have succeeded in changing the character. istics of ducks of one breed by injections of deoxyribonucleic acid from another, and that the modifica. tions continued to be identifiable in the progeny of the treated birds.

Because of the importance that must be attached to such revolutionary claims, and in the absence, as yet, of substantive evidence from repeat experiments, the work of Benoit and his colleagues should be subjected to eriticel scrutiny.

In the first place it might be suggested that, even with the most meticulous records, proof of somatic transformations of the kind described (size, weight, form of head, bill colour, carriage of body and the general aspect) would be difficult to establish in this species without an appreciation of the renge of variability.

This is because there is not only considerable lack of knowledge of the genetics of the duck, but at times the development of breeds depended upon predilection for improvement by the sporadic introduction of other varieties, and this has provided many so-called pure breeds with a cryptic hereditary constitution not always to be expected from their apparent origins.

Preliminary to the experiment the birds were obtained from a reputable breeder and the weekly
\end{abstract}

injections commenced when the Pekin ducklings were 8 deys old. Of thirty-six ducklings, twelve (3 males, 9 females) were chosen at random for injection of deoxyribonucleic acid derived from blood and testes of Khaki Campbell drakes, and the remainder kept as controls. Total amounts of deoxyribonucleic acid injected were $5 \mathrm{mgm}$. per bird for the males and $61 \mathrm{mgm}$. for the females over a period of 5 weeks and 19 weeks respectively. One male and eight females developed the pronounced somatic modifications described. The females matured normally and laid eggs which, fertilized by treated males, produced twenty-six ducklings, 73 per cent of them having atypically coloured bills, and a good number actually showing other somatic modifications.

Bill colour in the Pekin breed is orange-yellow, and in the Khaki Campbell a greenish black. It may be of significance that a defect of the Pekin listed in British Poultry Standards is "Black marks or spots on the bill".

Although considerable time would appear to have elapsed between the end of the injection period and the discovery of the modifications, the findings, if and when substantiated, would, like the proof of vegetative hybridization, have a tremendous impact on genetic theory and practice.

For the moment it would be as well to agree with Benoit and his colleagues that "Aujourd'hui, notre meilleure conclusion sers que nous n'avons aucune conclusion à vous présenter", and await the repetition and extension of this work by them and others who will, no doubt, be stimulated by the reports.

\section{Alan W. Greenwood}

${ }^{2}$ Benoit, J., LeRoy, P., Vendrely, C., and Vendrely, R., C.R. Acad. 65 Anné, No. 72, 1623 (1957).

\section{UNION OBSERVATORY, JOHANNESBURG}

\begin{abstract}
THE annual report of the Union Observatory, Johannesburg, for 1956 (which appeared in October 1957) follows the usual lines, and it will be sufficient to refer to the main events during the period under consideration. The $26 \frac{1}{2}$-in. refractor was used with the interferometer by Dr. W. S. Finsen for the measurement of double stars and the discovery of new ones on 135 nights, and on 68 nights for colour photography of Mars. In addition, Mr. J. Churms and Dr. W. H. van den Bos used it on 68 nights for the measurement of known double stars. Messrs. J. A. Bruwer and Churms, with a number of amateur astronomers who are members of the Transvaal Branch of the Astronomical Society of South Africa, used the 9-in. refractor on 179 nights for observations of planets, variable stars, etc., the amateurs rendering valuable assistance to the staff on visiting evenings and in many other ways. The results of the occultation observations were communicated to H.M. Nautical Almanac Office.
\end{abstract}

The Franklin-Adams telescope at the Hartbeestport Annexe obtained 178 plates for minor planets and 23 plates for comets, and the resulting positions were regularly communicated to the respective central bureaux of the International Astronomical Union at Cincinnati and Copenhagen. Dr. Finsen devoted much of his leisure time to the preparation of composite enlargements from the colour films of Mars obtained during the favourable opposition of 1954 and 1956. The card catalogue of double stars south of $-19^{\circ}$ dec. has been kept up to date, and information has been supplied to other astronomers on request.

With the 3-in. refractor sunspot counts were obtained on 281 days, the other days being overcast or unsuitable for reliable counts. The results have been regularly communicated to the Telecommunication Research Laboratory of the South African Council for Scientific and Industrial Research, the Magnetic Observatory at Hermanus and the Receiving 
Station of the South African Broadcasting Corporation at Panorama.

Under "Time Services", reference is made to improvements to the control circuits of the Diesel generator and to the vibrator power supply units so that the quartz clock installation is now practically independent of mains interruptions. A new frequency divider employing cold-cathode valves was built, and the stability of other frequency dividers improved. The performance of the ring crystal over short periods was rather more erratic than had been expected, and from Oetober onwards all the time and frequency equipment has been controlled by oscillator $4 A$ while further tests are being made. A twelve-channel frequency recorder, designed and built by the British Post Office, was delivered in June, and this recorder has been of very great value in keeping a continuous check on the performance of all parts of the time installation. A new cathode-ray oscilloscope comparison unit was built and this measures the reception time of time signals in terms of local time to one ten-thousandth of a second.

Under "Miscellaneous Public Services" reference is made to the Wiechert horizontal seismograph which was in operation throughout the year; local earth tremors and records of ten distant earthquakes; and records of rain have been sent monthly to the Bernard Price Institute for inclusion in its monthly Seismological Bulletin. Reference is also made to the installation of a synchronous motor drive on the twin telescope, and to the transfer of the Leyden Southern Station from Johannesburg to Hartbeestport.

\section{FEDERAL RESEARCH AND DEVELOPMENT EXPENDITURE IN THE UNITED STATES*}

$\mathrm{T}$ HE National Science Foundation has issued an analysis of the Federal Research and Development Budget for the fiscal years 1956, 1957 and 1958, in which latter year twenty-three agencies of the Federal Government allocated 3,400 million dollars for scientific research and development, an increase of nearly one-fourth on 1956. Actual expenditure increased from about 2,500 million dollars to almost 3,000 million dollars in 1957 and is expected to reach 3,300 million dollars in 1958. From 85 to 90 per cent of these funds are for the conduct of research and development, including the pay and allowances of personnel, actual expenditure increasing by 14 per cent in 1957, and it is expected to increase by 10 per cent in 1958 to 2,900 million dollars. Somo 1015 per cent of the total is on the expansion of plant and equipment, including the acquisition of land, and expenditure for these purposes increased from just over 200 million dollars in 1956 to an estimated 437 million dollars in 1958, mainly on plant or facilities for defence.

Of the twenty-three agencies, the Department of Defense and the Atomic Energy Commission together account for 88, 85 and 82 per cent of the total funds in 1956, 1957 and 1958, respectively, about 45 per cent of the Defense Department funds being administered by the Air Force. For 1957 and 1958, 672 million dollars were allocated by the Atomic Energy Commission, compared with 2,166 million and 2,111 million dollars, respectively, by the Defense Department. Allocations of the Department of Health, Education and Welfare for scientific research and development increased from 89 million dollars in 1956 to 200 million in 1958 , and of the 182 million allocated in 1957, 175 million were primarily by the National Institutes of Health for research on the diagnosis, cause and treatment of disease. The Department of Agriculture increased its allocation from 84 million dollars in 1956 to 108 million in 1957 and 132 million dollars in 1958; for the National Advisory Committee for Aeronautics, the corresponding figures are 66 million, 80 million and 94 million dollars; for the Department of the Interior, 38 million, 47 million and 53 million dollars ; for the National Science Foundation, 17 million, 48

* National Science Foundation. Federal Funds for Science 6 : The Federal Research and Development Budget, Fiscal Years 1956 , 1957 and 1958. Pp. iii +60 . Printing Office, 1957.) 40 cents. million and 47 million dollars; and for the Depart. ment of Commerce, 18 million, 25 million and 33 million dollars, respectively, the decrease for 1958 in the allocation by the National Science Foundation being because of the International Geophysical Year.

Of the 2,231 million dollars expended on the conduct of research and development in 1956,1,388 million was on development and 844 million on research, of which 157 million was on basic research. The corresponding figures for 1957 are estimated as 2,635 million dollars, 1,671 million, 964 million and 218 million, respectively, and for $1958,2,782$ million dollars, 1761 million, 1,021 million and 233 million, respectively. Of the expenditure on research in 1956 , 198 million dollars was on the biological sciences, 616 million dollars on the physical sciences, and 30 million on the social sciences ; in basic research, the corresponding distribution was 50 million, 104 million and 3 million dollarg. For 1957 the corresponding distribution in total research is estimated as 281 million, 627 million and 35 million, and in basic research 70 million, 143 million and 4 million dollars; and for 1958 in total research, 317 million, 637 million and 48 million, and in basic research, 83 million, 143 million and 6 million dollars. Subdivided again, total research expenditure on the biological sciences in 1956 included 99 million dollars on medical sciences and 44 million on agricultural sciences; for 1957 the corresponding estimates are 158 million and 53 million dollars, and for 1958 , 177 million and 59 million dollars. That on the physical sciences in 1956 included 6 million dollars on the mathematical sciences and $\mathbf{4 5 6}$ million dollars on the engineering sciences; corresponding estimates for 1957 are 7 million and 435 million dollars, respectively.

Of the 2,830 million dollars allocated for the conduct of research and development by the Federal Government in 1957, 48 per cent was spent on work performed by Government agencies, including pay and allowances of military personnel engaged in such work. Of the remainder, 35 per cent went to work carried out by profit organizations, about one-fourth of this going to research institutions administered by such organizations, 14 per cent went to educational institutions and the remsining 3 per cent to other institutions, including non-profit research institutions, foundations and hospitals. 